\title{
DINAMIKA IBADAH KURBAN DALAM PERKEMBANGAN HUKUM ISLAM MODERN
}

\author{
B. Hariyanto \\ UPBJJ Universitas Terbuka Bengkulu \\ Jl. Sadang Raya, Kelurahan Lingkar Barat, Kota Bengkulu 38225 \\ Email: hari_hamasaki@rocketmail.com
}

\begin{abstract}
Sacrifice is a necessity in the activities of Muslims every year. In addition to having a vertical dimension in the form of obedience to the commands of Allah SWT, sacrificial worship also has a horizontal dimension that is urgent for ukhuwah Islamiyah, namely concern for others and justice in realizing Muslim unity. The progress of the times achieved by modern civilization can actually be solutions that facilitate all forms of Islamic worship practices. Collective goat sacrifices, online sacrificial worship, sacrificial slaughter with mechanical devices, and sacrificial canning are some of the dynamics that occur in Muslim communities in the world. These dynamics must be addressed wisely in accordance with the objectives of the Sharia. The progress of the era with all its derivatives requires every Muslim to continue to strive to understand and explore the philosophical and axiological meanings of all the worship carried out, including in the implementation of sacrificial worship.
\end{abstract}

Keywords: sacrificial worship, modern Islamic law

\begin{abstract}
Abstrak: Ibadah kurban menjadi sebuah keniscayaan dalam aktifitas umat Islam setiap tahunnya. Selain memiliki dimensi vertikal berupa wujud ketaatan terhadap perintah Allah Swt, ibadah kurban juga memiliki dimensi horisontal yang urgen bagi ukhuwah islamiyah, yakni kepedulian terhadap sesama dan keadilan dalam mewujudkan persatuan umat Islam. Kemajuan zaman yang dicapai oleh peradaban modern sejatinya dapat menjadi solusi-solusi yang memudahkan segala bentuk praktik peribadatan umat Islam. Kurban kambing secara kolektif, pelaksanaan ibadah kurban secara online, penyembelihan kurban dengan alat mekanis, dan pengalengan daging kurban adalah beberapa dinamika yang terjadi di dalam masyarakat muslim di dunia. Dinamika-dinamika tersebut haruslah disikapi dengan bijak sesuai dengan tujuantujuan syariat. Kemajuan zaman dengan segala derivasinya menuntut setiap muslim untuk terus berupaya memahami dan menggali makna filosofis dan aksiologis dari semua ibadah yang dilakukan, termasuk dalam pelaksanaan ibadah kurban.
\end{abstract}

Kata kunci: ibadah kurban, hukum Islam modern

\section{Pendahuluan}

Ibadah kurban adalah ibadah yang dilakukan pada bulan Dzulhijjah, yaitu menyembelih hewan kurban dengan tuntutnan syariat. Kurban (udhiyyah) adalah sebutan untuk hewan ternak yaitu berupa binatang peliharaan yang disebelih atau dijadikan kurban pada hari raya kurban dan hari-hari Tasyriq semata-mata dilakukan untuk mendekatkan diri kepada Allah Swt. ${ }^{1}$

Ibadah kurban mulai diberlakukan pada tahun

${ }^{1}$ Syamsuddin Abu Abdillah Muhammad bin Qosim AsySyafi'i, Fathul Qarib, Jilid 2, (Kudus: Menara Kudus, 1983), h. 204. kedua hijriyah, sama seperti dua hari raya, zakat mal, dan zakat fitrah. Adapun pemberlakuannya ditetapkan berdasarkan Al-Qur'an, sunah, dan ijma ulama. Allah Swt., berfirman di dalam QS. Al-Kautsar/108: 2, yaitu:

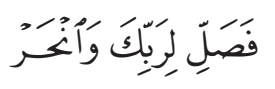

"Maka dirikanlah salat karena Tuhanmu; dan berkurbanlah."

Para imam mazhab sepakat bahwa udhhiyyah (penyembelihan hewan kurban) disyariatkan dalam Islam. Namun, mereka berbeda pendapat mengenai persoalan apakah kurban itu hukum- 
nya sunah atau wajib. Imam Maliki, Imam Syafi'i, dan Imam Hambali beserta beberapa ulama pengikut mazhab Hanafi berpendapat bahwa hukumnya adalah sunnah mu'akkadah. Sedangkan Imam Hanafi berpendapat bahwa hukum kurban adalah wajib bagi penduduk kota-kota besar, yaitu orang-orang yang sudah memiliki harta satu nisab. ${ }^{2}$

Ibadah kurban di Indonesia hukumnya adalah sunnah mu'akkad mengikuti mazhab Syafi'i. Lebih jauh lagi, mazhab ini menyatakan bahwa Ibadah kurban adalah sunnah muakkad bagi setiap individu, dan sunnah khifayah bagi keluarga sebuah rumah atau beberapa rumah di mana nafkah mereka menjadi tanggung jawab satu orang. Mudhahhi (orang yang berkurban) akan mendapatkan ganjaran pahala, dan tidak ada siksa yang dijatuhkan bagi orang yang meninggalkannya. ${ }^{3}$ Apabila seseorang yang berkewajiban memberi nafkah dalam satu keluarga telah mengerjakan udhhiyyah maka perintah berkurban kepada keluarga tersebut menjadi gugur. Adapun syarat disyariatkannya kurban ialah diperuntukkan kepada seorang muslim, baligh (dewasa) dan berakal sehat, serta memiliki kemampuan.

Ibadah kurban dilakukan dengan menyembelih hewan unta, sapi, dan kambing/ domba. Adapun syarat unta yang dijadikan hewan kurban yaitu telah berusia 6 (enam) tahun, sementara sapi dan kambing berusia 3 (tiga) tahun, sedangkan domba berusia 2 (dua) tahun. Umat muslim diperbolehkan berkurban dengan hewan jantan ataupun betina. Untuk unta dan sapi dapat dikurbankan untuk 7 (tujuh) orang, sedangkan seekor kambing untuk satu orang. ${ }^{4}$

Hingga hari ini, ibadah kurban masih tetap dilaksanakan di berbagai negara muslim di dunia modern. Berbagai kemajuan zaman di segala lini kehidupan masyarakat muslim modern berimplikasi pula kepada praktik ibadah kurban

\footnotetext{
${ }^{2}$ Muhammad bin 'Abdurrahman ad-Dimasyqi, Fiqih Empat Mazhab, (Bandung: Hasyimi, 2013), h. 186.

${ }^{3}$ Abdurrahman al-Juzairi, Fikih Empat Mazhab, Jilid 2, (Jakarta: Pustaka Al-Kautsar, 2015), h. 671.

${ }^{4}$ Imam Nawawi, Minhaj Ath-Thalibin, Jilid 2, (Jakarta: Pustaka Azzam, 2016), h. 325.
}

ini. Di Indonesia misalnya, ditemukan fenomena tentang kurban kambing secara kolektif atau secara kolektif (iuran), baik dengan jumlah sama rata maupun melalui sumbangan sukarela. Padahal secara umum kurban kolektif hanya dapat dilakukan untuk hewan sapi/kerbau dan unta, akan tetapi fenomena kurban kambing kolektif terjadi di beberapa instansi atau yayasan di berbagai daerah di Indonesia. Kurban tersebut ditujukan untuk tarbiyat al-ahkam (pendidikan hukum) bagi anak-anak dalam lingkup sekolah atau bagi para karyawan dalam lingkup organisasi.

Di samping kurban kambing secara kolektif (iuran), ada juga fenomena ibadah kurban yang dilaksanakan secara online. Menjamurnya teknologi jejaring memungkinkan sekup keagamaan dapat terinteraksi secara luas dan global, termasuk pula dalam ibadah kurban yang saat ini ada yang dipraktikkan dengan menggunakan teknologi secara online. Kurban online dilakukan dengan cara mengirimkan sejumlah uang kepada pengelola website untuk dibelikan hewan kurban dan kemudian disembelih sekaligus dagingnya dibagi-bagikan kepada pihak-pihak yang membutuhkannya. Sudah barang tentu pembagian dagingnya akan menyasar kepada masyarakat luas di luar wilayah domisili mudhahhi atau kepada masyarakat yang dianggap layak menerimanya menurut pertimbangan pengelola.

Tidak sampai di situ saja, di beberapa negara terdapat pula fenomena pengalengan daging sebagai dampak melimpahnya daging kurban seperti di Arab Saudi. Termasuk juga wacana dan fenomena penyembelihan hewan kurban dengan menggunakan mesin pemotong hewan sebagai efek dari melimpahnya sapi dan kambing kurban dan/atau minimnya tenaga manusia dalam pelaksanaan penyembelihannya.

Selanjutnya yang menjadi pertanyaan ialah bagaimanakah hukum kurban kambing secara kolektif yang terjadi pada beberapa instansi atau yayasan di Indonesia? Bagaimana keabsahan ibadah kurban online dan penyembelihan hewan kurban dengan mesin potong hewan? Serta bagaimana pula status hukum pengalengan daging kurban? Beberapa pertanyaan di atas "menggelitik" 
keingintahuan penulis untuk menemukan solusi dari berbagai permasalahan yang telah diajukan.

Beberapa invensi di bidang pelaksanaan ibadah kurban di dalam dunia muslim modern sebagaimana yang penulis paparkan di atas menuntut perlunya beberapa penjelasan yang logis sehingga ibadah kurban jauh dari prasangka dan keraguraguan.

\section{Kurban Kambing Secara Kolektif}

Sebagaimana yang penulis utarakan dalam latar belakang penulisan karya ini, bahwa kurban kolektif umumnya terjadi pada kurban yang menjadikan hewan-hewan besar seperti sapi atau unta sebagai obyeknya. Akantetapi, menyikapi fenomena adanya kurban kambing secara kolektif, bagaimanakah status hukumnya menurut hukum Islam? Kurban kambing secara kolektif yang dimaksudkan di sini ialah membeli hewan kurban kambing dengan menggunakan uang yang telah dikumpulkan secara bersama-sama atau kolektif, hal yang umumnya dipraktikkan dalam hal kurban sapi atau kerbau di Indonesia.

Kurban kambing secara kolektif semacam ini dijumpai pada instansi yang orang-orangnya belum sanggup membeli hewan kurban kambing secara individual, akan tetapi mereka memiliki semangat berkurban yang tinggi dan berharap semangat tersebut tetap ditanamkan secara kuat di dalam sebuah instansi itu. Madrasah atau yayasan pendidikan adalah contohnya, untuk menanamkan semangat berkurban dan semangat berbagi kepada orang lain maka diselenggarakanlah kurban kolektif di mana sasaran pesertanya adalah anak-anak sekolah dan para guru. Tiap-tiap individu memberikan sumbangan berupa uang tunai yang dikumpulkan untuk dibelikan seekor kambing. Baik uang tunai tersebut ditentukan nominalnya, maupun berbentuk sumbangan sukarela.

Di dalam sirah nabawiyah dijelaskan bahwa Nabi Muhammad saw melakukan ibadah kurban setiap tahunnya dengan dua ekor domba. Seekor atas nama dirinya sendiri dan yang seekor lagi untuk umatnya. Berdasarkan sirah di atas, maka dapat dipahami bahwa kurban kambing secara kolektif di dalam suatu instansi, yayasan, ataupun sekolah tetap dapat disebut sebagai ibadah kurban, hanya saja nilainya lebih rendah jika dibandingkan dengan ibadah kurban individual, yaitu satu ekor kambing sebagai udhiyyah untuk satu mudhahhi. Ibadah kurban kambing kolektif tersebut lebih dekat kepada amal sedekah yang juga akan diganjar pahala oleh Allah Swt.

Secara filosofis, kurban kambing kolektif ini tetap memberikankemanfaatan bagi mudhahhi yaitu: menanamkan sifat rela berkorban sejak dini kepada anak-anak, menekanakan sifat kedermawanan, kepedulian, dan solidaritas sesama muslim. Kurban kolektif juga dapat menjadi sarana latihan (riyadhah) bagi para guru atau anggota yayasan agar memiliki sifat rela berkorban dan ikhlas dalam beramal. Ia menjadi semacam "pemanasan" untuk menghadapi momentum kurban selanjutnya.

Kurban kambing secara kolektif memiliki tempat dalam fiqh tarbiyah, yakni untuk memberikan pendidikan bagi para pemula dengan harapan bahwa mudhahbi akan meningkatkan kemampuannya sehingga mampu menunaikan kurban syar'i pada tahun berikutnya.

Kendatipun memang belum ada fuqaha yang menyatakan kurban kambing secara kolektif dianggap sama dengan kurban syar'i dalam fiqh ibadah, namun kurban yang demikian tetap mengandung sisi pragmatis dalam kehidupan sosial di dalam masyarakat.

\section{Kurban Secara Online}

Persoalan kurban secara online sejatinya serupa dengan transaksi-transaksi online lainnya, yaitu sama dengan akad jual-beli. Adapun substansi kejujuran dan amanah menjadi hal yang dikedepankan dalam pelaksanaannya.

Dalam hukum Islam, terdapat beberapa syarat dan rukun agar suatu perbuatan muamalah dapat memiliki keabsahan. Rukun dan syarat yang dimaksud menurut Sayyid Sabiq antara lain:

a. Rukun: Ijab dan qabul;

b. Syarat-syarat:

1) Syarat subyektif (para pelaku akad) harus 
orang yang berakal dan mumayyiz (sudah dapat membedakan baik-buruk, mengerti hitungan harga, memiliki kemampuan memilih).

2) Syarat obyektif (barang yang diakadkan):

a) Barang yang diperjual-belikan harus suci;

b) Harus memiliki manfaat;

c) Harus dimiliki secara penuh oleh penjualnya;

d) Harus bisa diserahterimakan;

e) Harus diketahui keadaannya;

f) Harus ada dalam kekuasaan pemiliknya (maqbudh). ${ }^{5}$

Dalam hal ketentuan-ketentuan di atas dapat terpenuhi maka suatu kegiatan muamalah dapat dibenarkan. Adapun transaksi online dapat diqiyaskan kepada transaksi melalui surat, di mana kedua pelaku (baik penjual dan pembeli) tidak berada dalam suatu tempat yang sama (tidak satu majelis).Selain mengandung unsur transaksi jarak jauh, kurban secara online ini juga mirip dengan naqlu az-zakat, ${ }^{6}$ sebab besar kemungkinan bahwa daging kurban akan memiliki kemanfatan yang maksimal bilamana ia didistribusikan ke tempat lain.

Terdapat tiga pandangan berkenaan dengan distribusi zakat. Ahli figh mazhab Hanafi memperbolehkan mengirim zakat ke tempat lain yakni kepada kerabat yang miskin, masyarakat yang memiliki taraf kemiskinan lebih rendah. Mazhab Maliki juga memperbolehkan mengirim zakat ke tempat lain, yakni kepada mereka yang lebih membutuhkan semisal daerah bencana atau di tempat-tempat yang tengah mengalami musibah. Sama halnya dengan mazhab Syafi’i yang memperbolehkan mendistribusikan zakat ke tempat lain bilamana di tempat orang yang mengeluarkan zakat tidak ditemukan lagi penerima zakat dengan kata lain telah mengalami kelebihan zakat.

Jika kurban online diqiyaskan dengan naqlu

\footnotetext{
${ }^{5}$ Sulaiman Ahmad Yahya al-Faif, Ringkasan Fikih Sunnah Sayyid Sabiq, (Jakarta: Pustaka Alkautsar, 2013), h. 752.

${ }^{6}$ Pendistribusian zakat dalam bentuk uang ke daerah lain di luar wilayah domisili muzakki.
}

az-zakat karena kesamaan illat kemanfaatannya bagi pihak ketiga, maka bahwa kurban online diperbolehkan untuk diaplikasikan. Pada hakikatnya kurban online merupakan pendistribusian sejumlah uang untuk membeli hewan kurban untuk disembelih dan dibagi-bagikan dagingnya di tempat lain. Dalam ushulfiqh dinyatakan bahwa sepanjang suatu perbuatan muamalah itu berkaitan dengan muamalah ijtima ‘iyyah atau muamalah yang berorientasi kepada sosial kemasyarakatan, maka perbuatan muamalah tersebut dapat disandarkan kepada kaidah-kaidah fiqh yaitu:

a. Al-'Aadatu Muhakkamah

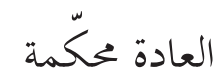

"Adat dapat dijadikan (pertimbangandalam menetapkan) hukum." 7

b. Al-ashlu fi al-mu'amalati al-ibahah illa ayyadulla dalilun 'alat tahrimiha

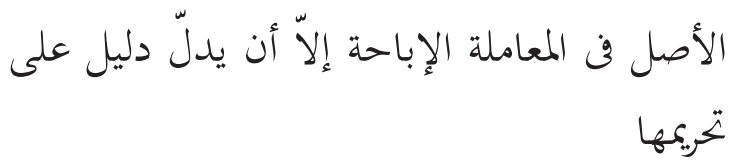

"Hukum asal dari semua bentuk muamalah adalah boleh dilakukan kecuali ada dalil yang mengharamkannya."

Berdasarkan kedua kaidah fiqh yang penulis kemukakan di atas, maka kurban secara online sebenarnya memiliki keabsahan di mata hukum agama,sehingga ia boleh dilaksanakan. Hanya saja perlu diperhatikan bahwa dalam pelaksanaannya dilakukan secara jujur dan amanah, sebab terdapat beberapa syarat yang harus dipenuhi oleh hewan yang akan dikurbankan, yaitu: hewan yang buta sebelah matanya (auraak), yang jelas pincang kakinya (arjaak), yang sakit badannya (maridhah), dan yang sakit otaknya serta hilang sumsumnya karena kurus. ${ }^{9}$ Juga tidak boleh dijadikan kurban yaitu hewan yang tidak bertanduk, terpotong ekornya, dikebiri, dan terpotong atau berlubang kurang h. 9 .

${ }^{7}$ A. Djazuli, Kaidah-kaidah Fikih, (Jakarta: Kencana, 2011),

${ }^{8}$ A. Djazuli, Kaidah-kaidah..., 130.

9 Taqiyuddin Abu Bakar bin Muhammad al-Husaini, Kifayatul Akhyar, Bagian II, (Surabaya: Bina Iman, 2007), h. 494 . 
dari separuh telinganya. ${ }^{10}$ Untuk itu, dibutuhkan sifat amanah bagi pihak pengelola kurban online, sehingga tujuan kurban yang mulia dengan memanfaatkan kemajuan teknologi informatika itu tidak dicederai dengan perbuatan-perbuatan yang menghilangkan hakikat syar'iyyahnya.

\section{Penyembelihan Hewan dengan Alat Bantu Mekanis}

Penyembelihan hewan yang dilakukan dengan bantuan alat mekanis yaitu dengan menggunakan mesin potong dipraktikkan di beberapa negara maju. Penyembelihan hewan dengan alat bantu mekanis ini diaplikasikan di wilayah yang mengalami surplus hewan kurban namun defisit dalam hal tenaga manusia sebagai pelaksana pemotongan hewan kurban secara manual. Penyembelihan hewan kurban dengan menggunakan mesin pemotong hewan ternak diaplikasikan dengan cara menekan tombol aplikator sehingga mesin secara otomatis akan bekerja memotong hewan satu demi satu.

Konsep penyembelihan ini dikembalikan kepada ketentuan penyembelihan pada umumnya dilakukan di dalam koridor hukum Islam. Operator mesin potong hewan haruslah seseorang yang telah dewasa (baligh), berakal sehat, selain itu ia harus menyebut nama Allah sebelum mengaplikasikan mesin, dan tempat yang dilukai oleh mata pisau mesin potong itu adalah tepat pada kerongkongan atau tenggorokan hewan yang akan dipotong.

Berkenaan dengan kesempurnaan penyembelihan hewan yang dapat dikuasai (hewan ternak peliharaan), Imam Syafi'i mengemukakan empat syarat tata caranya:

$$
\text { وكمال الذّكاة أربعة أشياء: قطع الحلقوم، والمريء، }
$$

"Penyembelihan yang sempurna mencakup empat perkara: (1) Memotong tenggorokan/saluran pernafasan, (2) Memotong tenggorokan/saluran

${ }^{10}$ Ibnu Qudamah al-Maqdisi, Umdatul Figh, (Solo: AlQowam, 2014), h. 93. makanan, (3) dan (4) Memotong dua urat leher."1

Penyembelihan hewan tersebut dilakukan pada interval waktu yang ditentukan syar $\ddot{i}$, yakni pada hari Idul Adha (setelah salat sunat Idul Adha) hingga berakhirnya hari tasyrik yang terakhir pada bulan Dzulhijjah. Allah Swt berfirman:

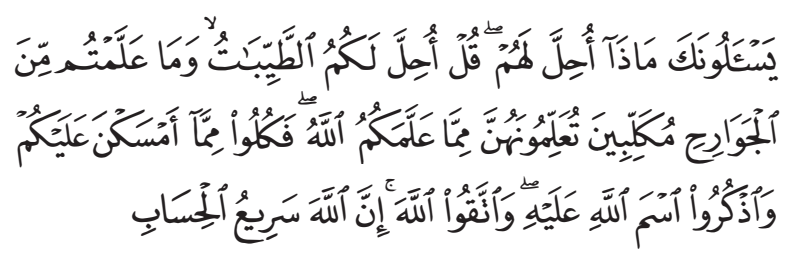

"Mereka menanyakan kepadamu: "Apakah yang dihalalkan bagi mereka?". Katakanlah: "Dihalalkan bagimu yang baik-baik dan (buruan yang ditangkap) oleh binatang buas yang telah kamu ajar dengan melatihnya untuk berburu; kamu mengajarnya menurut apa yang telah diajarkan Allah kepadamu. Maka makanlah dari apa yang ditangkapnya untukmu, dan sebutlah nama Allah atas binatang buas itu (waktu melepaskannya). Dan bertakwalah kepada Allah, sesungguhnya Allah Amat cepat hisab-Nya."

Perlu juga diperhatikan, bahwa pisau mekanis yang digunakan untuk memotong hewan kurban tersebut haruslah benda yang tajam (logam yang tajam, keramik yang tajam, plastik yang tajam, ataupun kaca yang tajam). Pelaksanaan kurban mekanis tersebut harus menghindari penggunaan benda-benda yang tidak tajam sebagai mata pisau mekanis, tujuannya adalah agar hewan kurban tidak tersiksa dalam pelaksanaan penyembelihan mekanis itu.

Di dalam musnad Imam Syafi'i, sebagaimana yang diriwayatkan Imam Bukhari dari Sufyan bin Uyainah dikatakan juga bahwa diperbolehkan menyembelih hewan dengan benda selain dari pisau, asalkan tidak menggunakan gigi dan kuku. Rasulullah saw bersabda:

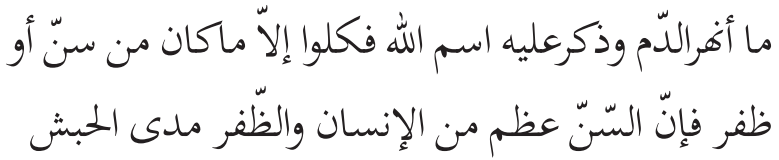

"Apa saja yang dapat mengalirkan darah dan disebutkan nama Allah, maka makanlah, kecuali

${ }^{11}$ Abu Syuja' al-Ashfahani, Fikih Praktis Madzhab Syafi'i (Matan Abu Syuja'), (Solo: Media Zikir, 2011), h. 416-417. 
iia menggunakan gigi atau kuku, karena sesungguhnya gigi itu merupakan bagian dari tulang manusia dan kuku ini adalah pisaunya orang-orang Habasyah." 2

Pada tempat yang lain diperoleh pula ketentuan di dalam hadis Bukhari No. 5506, bahwa diperbolehkan memakan hewan sembelihan dengan alat-alat penyembelih selain dari gigi dan kuku.

$$
\begin{aligned}
& \text { حدّ ثنا قبيصة: حدّ ثنا سفيان عن أبيه, عن عباية بن } \\
& \text { رفاعه, عن رافع بن خديج قال: النّي: كل - يعني - } \\
& \text { ما أغر الدّم - إلاًّ السّنّ والظّفور رَّر }
\end{aligned}
$$

"Qabishah menyampaikan kepada kami dari Sufyan, dari ayahnya. Dari Abayah bin Rifa'ah dari Rafi' bin Khadij yang mengatakan bahwa Nabi saw., bersabda: 'Makanlah hewan yang disembelih dengan alat yang dapat mengalirkan darah selain gigi dan kuku."'l3

Berkenaan dengan teknis penyembelihan, Zainuddin Abdul Aziz al-Malibary menyatakan:

"Cara menyembelih binatang darat yang dapat dikuasai adalah dengan memotong putus urat bulqum (kerongkongan, yaitu jalan nafas) dan urat mari' (jalan makanan di belakang urang hulqum). Pemotongan ini dilakukan dengan menggunakan benda tajam selain tulang, gigi, dan kuku, seperti misalnya logam, bambu, kaca, emas atau perak. Maka menjadi haram dimakan bila binatang itu mati tertimpa benda berat, baik berupa logam atau bukan, misalya peluru, sekalipun membuat cucuran darah atau bahkan memutuskan kepala. Atau bila disembelih memakan logam tumpul yang tidak dapat memutuskan kecuali dengan adanya tekanan yang kuat dari penyembelih. Karena itu, seyogyanya cepat-cepat memutus urat bulqum sedemikian rupa, sehingga binatang tidak mengalami gerak ajal sebelum urat itu putus dengan sepenuhnya." ${ }^{14}$

Yusuf al-Qardhawi juga menyatakan bahwa:

"Penyembelihan yang sesuai menurut syariat, hanya bisa sempurna jika telah terpenuhinya

${ }^{12}$ Imam Syafi'i, Musnad Imam Syafi'i - Jilid 2, (Jakarta: Pustaka Azzam, 2008), h. 623.

13 Abu Abdullah Muhammad bin Ismail al-Bukhari, Ensiklopedia Hadis: Shahih Bukhari 2, Jakarta: Almahira, 2012, h. 432.

${ }^{14}$ Zainuddin Abdul Aziz al-Malibary, Fathul Müin - Jilid 2, (Kudus: Menara Kudus, 1980), h. 138. syarat-syarat sebagai berikut: Pertama, binatang tersebut harus disembelih atau ditusuk dengan suatu alat yang tajam yang dapat mengalirkan darah dari binatang tersebut, baik alat itu berupa batu ataupun kayu. Kedua, penyembelihan itu harus dilakukan di leher binatang tersebut. Yaitu kematian binatang tersebut adalah sebagai akibat dari terputusnya urat nadi atau kerongkongannya. Penyembelihan yang paling sempurna, yaitu terputusnya kerongkongan, tenggorokan, dan urat nadi. Ketiga, tidak disebut nama selain Allah dan ini sudah disepakati oleh semua ulama. Sebab orang-orang jahiliyah mendekatkan diri kepada tuhan dan berhalanya dengan cara menyembelih binatang, yang ada kalanya mereka menyebut berhala-berhala itu ketika menyembelih, dan ada kalanya penyembelihannya itu diperuntukkan kepada sesuatu berhala tertentu. Untuk itulah maka Alquran melarangnya, yaitu sebagaimana disebutkan di dalam Surat al-Maaidah/5 ayat 3. Keempat, menyebut nama Allah ketika menyembelih sebagaimana yang diungkapkan Alquran Surat al-An'am/6, ayat 118 dan ayat 121."15

Status hukum hewan-hewan yang disembelih oleh operator secara mekanishukumnya halal untuk dikonsumsi, asalkan memenuhi syarat penyembelihan dan sesuai tuntunan syariat. Jika hasil buruan binatangpemburu saja hukum halal (asalkan disebut nama Allah sebelum binatang pemburu itu dilepas), maka apalagi status hukum hasil sembelihan mekanis yang melibatkan operator yang memenuhi kriteria penyembelihan sesuai syariat.

Rasulullah saw tidak mempersulit urusan ini sesuai hadis yang diriwayatkan oleh 'Aisyah ra. dalam hadis Bukhari No. 5507:

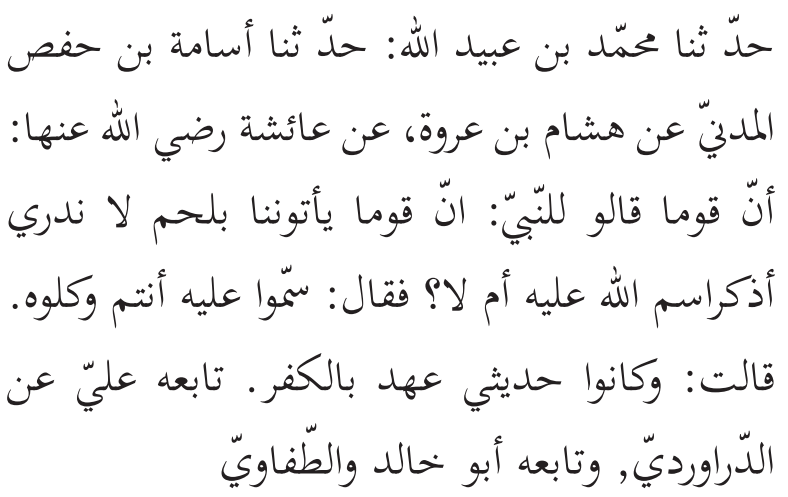

15 Yusuf al-Qardhawi, Halal dan Haram, (Bandung: Jabal, 2007), h. 67-68. 
"Muhammad bin Ubaidullah menyampaikan kepada kami dari Usamah bin Hafsh al-Madani, dari Hisyam bin Urwah, dari ayahnya, dari Aisyah bahwa ada sekelompok orang berkata kepada Nabi, 'Orang-orang memberi kami daging. Kami tidak tahu apakah mereka menyebut nama Allah (ketika menyembelihnya) atau tidak.' Beliau bersabda, 'Sebutlah nama Allah dan makanlah daging tersebut.' 'Aisyah berkata 'mereka masih dekat dengan kekufuran (baru masuk Islam).' ('Ali meriwayatkan hadis yang sama dari adDarawardi. Sementara Abu Khalid dan athThufawi meriwayatkan hadis ini dari 'Ali. "I6

Berdasarkan keterangan-keterangan di atas, maka ketentuan pokok-pokok ajaran Islam yaitu kepatuhan dan kemaslahatan haruslah lebih diutamakan dalam segala hal, termasuk dalam hal makanan. Dengan demikian, penyembelihan hewan kurban dengan menggunakan alat mekanis dapat diterapkan dengan tetap memperhatikan ketaatan kepada tuntunan syar’i dan memperhatikan kemaslahatan yang menjadi tujuan dari hukum Islam.

\section{Pengalengan Daging Kurban}

Penyembelihan kurban secara serentak di berbagai penjuru negeri berimplikasi kepada melimpahnya daging kurban yang tentunya menjadi persoalan tersendiri bagi umat Islam di negeri tersebut. Arab Saudi dan beberapa negara muslim lainnya merupakan contoh kasus surplus daging tersebut.

Banyak pihak yang mencoba memikirkan solusi terhadap kemanfaatan daging kurban yang melimpah tersebut, utamanya pemanfaatan yang efektif dalam jangka panjang sehingga daging kurban itu dapat dinikmati oleh umat Islam seluas-luasnya.Salah satu ide tentang pemanfaatan daging kurban dalam jangka waktu yang lama dan menjangkau masyarakat muslim secara luas ialah pengalengan daging kurban. Awalnya ide tersebut mendapatkan kritik-kritik dari beberapa ahli figh, salah satunya dari Lajnah Daimah Saudi Arabia. Mereka mengatakan bahwa praktik yang

${ }_{16}$ Abu Abdullah Muhammad bin Ismail al-Bukhari, Ensiklopedia Hadis..., h. 432. demikian tidak dijumpai pada masa Rasulullah saw. Akan tetapi, mencermati kemanfaatan yang lebih luas dan menghindari kesia-siaan maka akhirnya fuqaha Arab Saudi menyetujui untuk melakukan pengalengan daging kurban demi kepentingan yang lebih luas dan lebih besar. Hal tersebut dilakukan karena melimpahnya kurban dan hadyuldam pada musim haji di Tanah Suci, sehingga akan lebih bermanfaat jika daging-daging yang tidak habis dibagikan itu dikalengkan kemudian didistribusikan kepada saudara muslim di negara lain yang lebih membutuhkannya. Terutama di negara-negara yang tengah dilanda peperangan, ataupun di negaranegara yang mengalami kesulitan (paceklik) akibat bencana alam. Berkenaan dengan persoalan ini Bin Baz memfatwakan:

"Kewajiban kaum muslimin adalah tunduk kepada syariat Allah dan melakukannya. Jika terdapat kesalahan atau kekurangan dari manusia dalam pelaksanaannya, maka wajib memperbaiki dan memberikan pertolongan untuk hal tersebut. Seperti yang terjadi dalam penyebelihan sebagian kurban dan tidak adanya orang yang memakannya. Ini adalah kesalahan yang harus ditangani oleh para penguasa dan semua manusia. Setiap muslim harus peduli terhadap kurbannya sehingga dapat dibagikan kepada orang-orang miskin, atau dia memakannya atau dihadiahkan kepada kawan-kawannya. Adapun dengan meninggalkan kurban di tempat-tempat penyembelihan dan tidak dimanfaatkan, maka demikian itu tidak cukup baginya. Adapun kewajiban para penguasa adalah memberikan pertolongan pada hal tersebut dengan membagikan daging-daging kurban kepada orang miskin pada waktunya, atau memindahkan ke tempat-tempat pendiginan untuk dapat dimanfaatkan setelah itu dan tidak rusak. Ini adalah kewajiban para penguasa. Mereka insya Allah akan melakukan hal ini, sedang ulama akan selalu menasihati dan mengingatkan mereka untuk hal tersebut." 17

Dengan demikian, dilakukannya pengalengan untuk membuat daging kurban menjadi awet dan dapat dimanfaatkan di masa yang akan datang sejalan dengan kaidah pokok dalam hukum Islam yakni: "Jalb al-mashalihi wa daf'u al-mafaasidi."

\footnotetext{
${ }_{17}$ Muhammad bin 'Abdul 'Aziz al-Musnad, Fatwa-fatwa Haji dan Umrah, Jakarta: Pustaka Asy-Syafi'i, 2007, h. 380-381.
} 


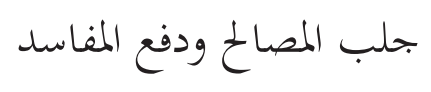

"Meraih yang maslahat dan menolak yang mafsadat."

Pendistribusian daging kurban sesungguhnya memiliki dimensi fiqh sosial dan ibadah ta’aqquli (ibadah yang berdimensi pada akal). Berangkat dariadanya asas kemaslahatan dan tidak adanya larangan tentang pelaksanaannya, maka pengalengan daging kurban dan pendistribusiannya ke berbagai wilayah yang memerlukannya dapat dilakukan kapan saja, bahkan di luar hari tasyriq sekalipun.

Berbagai kemudahan-kemudahan dalam aplikasi kurban secara teknis tersebut ditujukan untuk kemaslahatan umat Islam secara luas dan tetap sesuai dengan maksud dari syariat itu sendiri.

\section{Penutup}

Kemajuan zaman dengan segala derivasinya menuntut setiap muslim untuk menyelaraskan modernitas dengan kewajiban dalam beribadah, termasuk di dalamnya adalah ibadah kurban. Ibadah kurban dengan cara kolektif untuk hewan kurban berjenis kambing tetap memiliki nilai ibadah di samping nilai tarbiyah yang ada dikandungnya. Kendatipun tidak seutama ibadah kurban yang ditentukan oleh syariat, kurban kambing yang dilakukan secara kolektif tersebut dapat menjadi motivasi dan sarana latihan bagi mudhahhi yang menunaikannya.

Penyembelihan hewan kurban dengan menggunakan mesin potong dapat dilakukan dengan tujuan-tujuan kemaslahatan dengan tetap memperhatikan mekanisme penyembelihan sesuai dengan tuntunan syariat. Adapun kurban online dapat dilakukan asalkan tetap memenuhi rukun dan syarat transaksi muamalah serta didasari dengan kejujuran dan sifat amanah yang dimiliki oleh pengelolanya. Pengalengan daging hewan kurban dapat menjadi solusi terhadap berlimpahnya daging kurban di suatu daerah. Adapun pendistribusian daging hewan kurban dalam bentuk daging yang dikemas di dalam

\footnotetext{
${ }^{18}$ A. Djazuli, Kaidah-Kaidah..., h. 6.
}

kaleng dapat diqiyaskan dengan distribusi zakat ke daerah lain.

Seluruh pembaharuanyang memberikan manfaat kepada penerimanya dapat diterapkan di dalam kehidupan masyarakat muslim asalkan ia dilaksanakan dengan memperhatikan ketentuan syariat dengan mengedepankan maslahah mu'tabarah (maslahat yang dapat diterima) berdasarkan dalil-dalil yang rajih.

\section{Pustaka Acuan}

Ashfahani, Abu Syuja' al-, Fikih Praktis Madzhab Syafi'i (Matan Abu Syuja'), Solo: Media Zikir, 2011.

Bukhari, Abu Abdullah Muhammad bin Ismail al-, Ensiklopedia Hadis: Shahih Bukhari 2, Jakarta: Almahira, 2012.

Dimasyqi, Muhammad bin 'Abdurrahman ad-, Fiqih Empat Mazhab, Bandung: Hasyimi, 2013.

Djazuli, A., Kaidah-kaidah Fikih, Jakarta: Kencana, 2011.

Faifi, Sulaiman Ahmad Yahya al-, Ringkasan Fikih Sunnah Sayyid Sabiq, Jakarta: Pustaka Alkautsar, 2013.

Husaini, Taqiyuddin Abu Bakar bin Muhammad al-, Kifayatul Akhyar, Bagian II, Surabaya: Bina Iman, 2007.

Juzairi, Abdurrahman al-, Fikih Empat Mazhab, Jilid 2, Jakarta: Pustaka Al-Kautsar, 2015.

Malibary, Zainuddin Abdul Aziz al-, Fathul Mu'in, Kudus: Menara Kudus, 1980.

Maqdisi, Ibnu Qudamah al-, Umdatul Fiqh, Solo: Al-Qowam, 2014.

Musnad, Muhammad bin 'Abdul 'Aziz al, Fatwafatwa Haji dan Umrah, Jakarta: Pustaka AsySyafi'i, 2007.

Nawawi, Imam, Minhaj Ath-Thalibin, Jilid 2, Jakarta: Pustaka Azzam, 2016.

Qardhawi, Yusuf al-, Halal dan Haram, Bandung: Jabal, 2007.

Syafi'i, Imam, Musnad Imam Syafi'i, Jakarta: Pustaka Azzam, 2008.

Syafi'i, Syamsuddin Abu Abdillah Muhammad bin Qosim Asy-, Fathul Qarib, Jilid 2, Kudus: Menara Kudus, 1983. 